\title{
Symbolic Meaning of the Ornamental Diversity of Cirebon Batik Pegajahan
}

\author{
KOMARUDIN KUDIYA, ${ }^{1}$ \\ SETIAWAN SABANA, 2 \\ AGUS SACHARI 3 \\ 1, 2,3. Doctor Study Program, Fine Arts and Design Study Program ITB \\ E-mail : kkudiya@ymail.com, setiawansabana@yahoo.com, asachari@gmail.com
}

\begin{abstract}
Batik Pegajahan Cirebon merupakan hasil dari proses olah cipta, rasa, karsa, juga pemikiran yang panjang dari orang-orang yang memiliki keahlian dalam menginterpretasi suatu kondisi perilaku masyarakat (Keraton) Cirebon, yang kemudian mengadaptasikan kedalam bentuk seni budaya kain batik melalui proses kreatifitas para perajinnya. Batik Pegajahan ini tumbuh dan berkembang di dalam lingkungan masyarakat (Keraton) Cirebon, meliputi : Keraton Kasepuhan, Keraton Kanoman, Keraton Kacirebonan, dan Keprabonan.

Kajian ini akan menjelaskan narasi simbolik yang terdapat di dalam ragam hias batik Pegajahan Cirebon. Pembahasan berdasarkan unsur visual simbolik secara sistematik terhadap ragam hias batik Pegajahan yang berlandaskan pada sikap ajaran Tarekat Syattariyah dan perilaku masyarakat (Keraton) Cirebon, wujud kearifan lokal yang tercermin dalam unsur-unsur simbolik-estetik.

Penelitian menggunakan metode deskriptif-analitis dan etnografi, dalam menguraikan narasi simbolik yangterdapat pada Batik Pegajahan Cirebon. Hasil yang diperoleh, berupa data-data visual lengkap beserta narasi simbolik dalam Batik Pegajahan Cirebon, yang merepresentasikan perilaku masyarakat (Keraton) Cirebon secara signifikan; sehingga dapat digunakan sebagai referensi penelitian lanjutan dalam merekonstruksi, mereproduksi, dan memformulasikan ragam hias tersebut sebagai dasar perancangan atau panduan bagi masyarakat perbatikan (Keraton) Cirebon khususnya.

Kata kunci : Narasi Simbolik, Ragam Hias Batik Pegajahan danTarekat Syattariyah
\end{abstract}

Cirebon Batik Pegajahan is the result of the creative process, feeling, intention, also long thought of people who have expertise in interpreting the condition of people's behavior of Cirebon (palace), which was then adapted into a form of art and culture of batik fabric through a process of creativity of the craftsmen. This Batik Pegajahan grows and develops within the community of (palace) Cirebon, including: Kasepuhan Palace, Kanoman, Kacirebonan, and Keprabonan.

This study will explain the symbolic narrative contained in Pegajahan Cirebon batik decoration. The discussion is based on the systematic symbolic visual elements of the Pegajahan batik decoration which is based on the teachings of the Tarekat Syattariyah attitudes and behavior of (palace) Cirebon society, form of local wisdom that is reflected in the symbolic-aesthetic elements.

The research used descriptive-analytic method and ethnography, in describing the symbolic narrative found in Batik Pegajahan Cirebon. The results are in the form of visual data complete with symbolic narratives in Batik Pegajahan Cirebon, which represents behavior of (palace) Cirebon people significantly; so it can be used as reference for further research in the reconstruction, reproducing, and formulating such ornaments as the basis for designing or guidance for the people of batik (palace) Cirebon in particular.

Keywords: Symbolic Narratives, Decoration of Batik Pegajahan and Tarekat Syattariyah 


\section{INTRODUCTION}

Batik Cirebon which is part of Indonesian batik as well as part of the cultural product of heritage which is now known worldwide. A piece of batik can tell the greatness of Indonesian culture that are polite, cultured and civilized. Therefore, batik can be seen as an object that continues to be legendary and give extrinsic and intrinsic meaning to the world of Nusantara fabric

Batik Cirebon can be divided into Cirebon batik and batik outside the city of Cirebon. Principal ornamental motif of Cirebon batik is dominated by the influences of sultanate culture in Cirebon and the influence of Chinese culture that has been stylized, but prefers the meaning contained in the entire Cirebon palace batik decoration. Although the motif indicates the influence of Chinese culture physically, but in the development the motif is based on religious teachings of Islam. The spirit of Batik Keraton Cirebon is the embodiment of the tarekat in Cirebon. The beauty of tarekat is reflected in Cirebon batik motif, by implying message contained in the pattern of batik (Irianto, et al. 2012).

In the region of Cirebon there are areas which initially produce batiks with batik keratonan decorative pattern taking the themes of artifacts and culture around the palace or special order ornament of family palace, in addition to the craftsmen also made batik with coastal decorative theme.

According to the results of interviews with a Cirebon culturalist, Drs. Hashim Raofan M.Pd batik Pegajahan born in Cirebon sultanate environment are more likely to present a unique batik decoration full of symbolic meaning, and most of the decoration is strongly influenced by the teachings of Islam through a group of followers of Tarekat Syattariyah. Pegajahan batik decoration was created by the students who run Islamic Shari'a in accordance with the depth in the running of the Islamic Shari'a; it is very interesting to be disclosed scientifically because it has never been done by previous researchers.

\section{BATIK PEGAJAHAN}

Prince Insan Martawijaya (born in the early 1900s) still inherited the family line of Sultan Kanoman living in the area of Pegajahan Cirebon located not far from Kanoman Palace, is one of the originators of the founding of batik Pegajahan. Further development of batik Pegajahan was continued by his son named Prince Adhi Mulya estimated born in 1940. Prince Adhi Mulya has several sons and daughters including Eagle Deddy Adisaputra bin P.H. Adhi Mulya and Elang Yoppy Idopi bin Achmad P.H. Adhi Mulya. Direct interviews conducted by the author in the residence of P.H. Adhi Mulya in Pegajahan region in March 2013 with two sons P.H. Adhi Mulya (deceased) were the source of batik Pegajahan history and old batik artifacts, relics of the elder used as a source of research to uncover the complete history of batik Pegajahan.

Based on the direct narrative delivered by Elang Deddy Adisaputra the Prince Insan Martawijaya was still alive around 1940 and he was actively teaching the Islamic religion with the school of the Tarekat Syattariyah to the disciples. The activity of making batik was done at the time these students were having free time outside of learning time. The students of PH. Insan Martawijaya who worked on the process of making batik included Mr. Kibol and Bi Minidari in the area of Gamel Plered Cirebon in 1970, after both of them died, most of the works were given to one of his faithful followers, $\mathrm{Mr}$ Madmil (late) originated from the village of Trusmi Plered Cirebon. According to Elang Dedy Adisaputra that part of batik decoration work of the Prince's Insan had been produced by Mr. Madmil. Batik produced by the family of Prince Insan Martawijaya are characterized by the ornament with elements of animal, i.e Elephant, wild chicken, gravestone, Pandan Wangi plant, Wadasan and Megamendung.

Batik decoration created by P.H. Insan Martawijaya have largely been realized in the form of batik cloth, and most of the design is still limited to a process lengrengan ( $\mathrm{a}$ form of decoration that is drawn on a piece of white cloth using wax painted by canting tool) and to this day the fabrics are still stored good and have not reached the stage of coloring in the sense that the fabrics are still unfinished to become batik cloth. 


\section{PETAREKANPEGAJAHAN AND DAN SYAT- TARIYAH TEACHINGS}

In the early days of the process of Islamization in Indonesia, especially in Java, Java-Hindu mystical conception that has evolved over many years has been used by propagator of Islam, known as para wali (the guardian), as one of the channels to spread Islam in Java. Javanese-Hindu mystical conception was synchronized and updated with Islamic mystical elements, contained in the teachings of Sufism (Tjandrasasmita 1977: 122-123, 144).

Tarekat Syattariyah is the school of tarekat, first appeared in India in the 15th century. The tarekat was ascribed to figure who popularized and developed meritorious, Abdullah ash-Syattar. Initially, the tarekat was better known in Iran and Transoksania (Central Asia) with the name of Isyqiyah. While in the region of the Ottoman Empire, the tarekat is called Bistamiyah. Both names are derived from the name of Abu Yazid al-Isyqi, which is considered as the main figure. But in the subsequent development Tarekat Syattariyah was not considered as a Sufi branch of the union anywhere. The tarekat is considered a tarekat with typical characteristics in belief and practice (Achmad; 2010).

The spread of Islam in Cirebon generally followed the tradition of Islamic learning found in the entire region of Java. As illustrated by Dhofier (1985; 18-24), every Javanese is taught and officially pronounces the shahada at least once in a lifetime, i.e when they get married. But generally, Javanese shahada have been read out in the ears of newborns. (Muhaimin; 294).

The history of the teachings of Islam from Tarekat Syattariyah is obtained from the book by AG Muhaimin; it is told that Mbah Buyut Kriyan or Kyai Anwaruddin Kriyani al Malebari who married Nyai Nurillah the daughter of Kyai Muta'ad (17851852) was a Sufi who came from India. Kyai Muta'ad is the granddaughter-in-law of Mbah Muqoyyim the founder of pesantren Buntet. Mbah Muqoyyim first started teaching Islam in the area of Buntet, Kedungmalang block. He was once chased down by Dutch troops and then fled or hid. Then in 1758, he founded pesantren (boarding school) in the area called Gajah Ngambung Buntet block.
One of his first students was Prince Khaeruddin, son of Sultan Kanoman (Khaeruddin I) (Muhaimin; 312-314).

The subsequent development was delivered by Raofan Hasyim that the teachings of Syattariyah developed among Kanoman palace which then the group of followers of the teachings of Syattariyah Qadiriyya wa Naqsabandiyah was born having some students in the area of Pegajahan which is still the royal family of Kanoman palace.

\section{THE DEVELOPMENT OF BATIK KERATON CIREBON}

According to Bambang Irianto a culture stylist of Kaceribonan palace said that the traditional batik of Keraton Cirebon which is a product of art, in the history of its long development until the arrival of Islam in Cirebon, has been colored with the meaning from the standpoint of tarekat which has a strong influence on religious life in the palace of Cirebon. The art of traditional batik Keraton Cirebon is the expertise of creating a pattern or image on the cloth of high quality, the production of which in particular has always held fast to the hereditary customs and habits, since the reign of Prince Walangsungsang Cakrabuana who held the title of Sri Mangana in the year 1469 AD, then followed by Syarif Hidayatullah (Sunan Gunung Jati) in the year 1479 AD to the present.

In its development, Keraton Cirebon today is divided into three palaces in which each has its own batik decoration characteristics, The typical batik of Kasepuhan Palace is Singa Barong, Kanoman has typical batik Paksi Naga Liman, Kacirebonan has a typical batik associated with Bintulu and Kaprabonan typical batik motif is Dalung and a motif without animal drawings.

The return of the popularity of batik Cirebon about the last thirty years has become a pride of Cirebon society in general (Irianto; 53). Made Casta said that in reality batik in Cirebon area is unique in its visual expression compared to other centers of Coastal batik. This is caused by the role of the two palaces in Cirebon. The two palaces are, Kasepuhan and Kanoman that are very significant in determining the growth and development constellation 
of the Cirebon batik. Cirebon batik is now growing and developing with coastal batik and keratonan genre (Casta; 57-58). Casta further said that the Cirebon batik keratonan is very thick with symbolic meaning related to Cirebonan cosmology. That is, batik is not just an expression of visual aesthetic, but it contains a particular value system that is believed and lived by the society, especially the palaces in Cirebon. Therefore the keratonan motif typically stores or has a symbolic meaning (Casta; 59).

\section{AESTHETIC VARIETY OF ORNAMENTAL ART IN ISLAM}

Aesthetics is often defined as a philosophy of beauty or art. As a branch of philosophy or independent science, it is apart from metaphysics, logic and ethics, and theology, have occurred since the 18th century and the views of independent science is retained to the present day. The earliest book that saw aesthetics as a separate science is Baumgarten work, a German rationalist philosopher. Baumgarten famous work is Aesthetica (1750). The word 'Aesthetica' is derived from the Greek word 'aesthetis' meaning observation of the senses or something that stimulates the senses. (Hadi; 33)

The problems of beauty and art work are related to higher human desire, that is spiritual experience and intellectual satisfaction (Pabitrakumar; 1990). Art is also related to morality and religion. Imam al-Ghazali in his book Kimiya-i-Sa'adah (Chemistry of Happiness) said that the effects of the artwork on the human psyche is very significant, and therefore determines the moral and appreciation of religiousity

It is in line with batik painting, known as the traditional batik art. Batik artists, in this case, the students who practice tarekat, in pouring their ideas and imagination in making decorative batik will form animal motifs by distillation as far as possible and does not seem clear that the paints are in the form of living beings. Therefore images in the art of batik is inanimate. Even the image of animal is presented like tendrils of plants which explicitly resemble the form of a living, but not exactly like the original form of animals.

\section{RESEARCH METHODS}

A visual search of the existence of Pegajahan Cirebon batik ornament characterized by Cirebon palace batik as a case study, is the concrete implication of the teachings of Tarekat Syattariah, which is a form of local wisdom of the archipelago cultural products reflected in the aesthetic symbolic elements: Thus the study was done using descriptive-analytic and aesthetic methods (Sachari, 2003), and ethnographic method (Spradley, 2006), supported by historical approach which become a way or strategy to find answers to the problems of history as a discipline: how the past is known, how is the form of past knowledge, how is the objectivity of historical writing, causality in history, whether history is deterministic or open, and so on (Yudoseputro, 2005), in detailing the objects of Pegajahan Cirebon batik that are affected by these teachings.

The ethnographic methods is aimed at defining culture as a system of human knowledge acquired through the learning process, which they use to interpret the world around them, and also to develop strategies for behavior to face with the world around them.

The main data collection techniques are observation-participation, as well as open and deep interviews conducted within a relative time, not a short visit with a list of questions that are structured as in survey research (Spradley, 2006). Furthermore, aesthetic method is ised to examine design aspects in the form of visual batik seen from the shape, color, material, decorative, patterns, that becopme elements of aesthetic on batik of Pegajahan Cirebon (Sachari, 2003), with a view to explore the forms that exist in batik decoration of Sirah Liman, wild chicken, Gajah Pungkur (Gajah Mungkur) and Kijing Bungkem, as well as blends of composition in the form of batik products.

\section{DISCUSSION}

According to Iwan Acep Saidi, art work can be called a narrative if there is a relation between two or more visual elements that build a story. The visual element in question includes events, characters, settings (space), plot (time), point of view, and word pattern.Visual work tells story in visual signs that require a further comprehensive understanding than 
literary texts in verbal language. Therefore, the narrative in visual arts is called symbolic narrative, a story that is built through a relation between symbolic elements. Symbolic narration in visual arts are more developed implicitly (in absentia) or patterned on the appreciator's minds after seeing the works (after image). In a broader scope, through an analysis of the structure and the symbolic narrative patterns the relationship between the structure and patterns with the structures and patterns of culture as a place where artists live and work are also found, that is the very prominent habit of telling story and has been preacticed for decades as a cultural heritage.

Batik Pegajahan produced by the family of Prince Insan Martawijaya was partly characterized by decorative elements of animal like elephant, Pandan Wangi, wild chikens, Wadasan and Megamendung. Others are influenced by Kanoman decorative coloring of some existing designs. Based on the information obtained from Elang Yoppy, almost all the batik found in the Peguron Pegajahan has core element of Tarekat teachings embodied in the image of batik. Some names of batik motifs created in Pegajahan include Sirah Liman, Ayam Alas, Pungkur Gajah (Gajah Mungkur) and Kijing Bungkem.

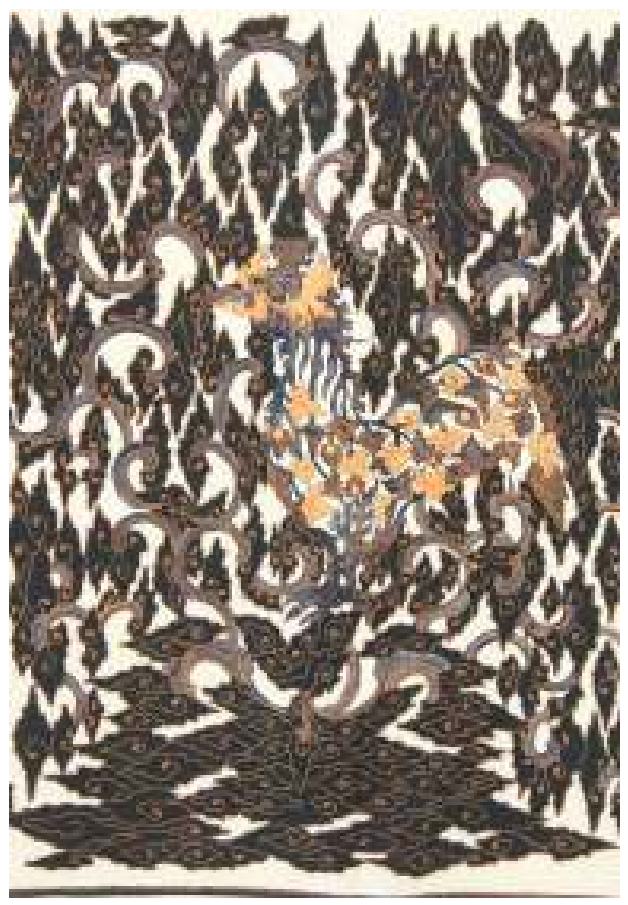

Ayam Alas (Wild Chicken) ornament was created by Prince Jabir / Prince Sipat. The composition of the ornament consists main motif element, ie Ayam Alas, form of a partridge which is a stylized form of kangkung (swamp cabbage ) Patran (leaf) that make up the rooster. Supporting ornaments: tendril ornament of megamendung rooted under a chicken leg pads (lelemah) then spread upwards towards the front and rear of wild chickens in the background (background) of wild chicken motif. The megamendung tendrils take the form of lung - lungan (arch motif or niche) towards opposites engraving curved. The philosophy of this decoration is Ayam Alas (wild chicken), a symbol of prince Sabakingkin's valor (Maulana Hasanuddin), the son of Sunan Gunung Jati in spreading Islam in Pulasari Wahanten Girang (Banten Girang). According to the Chronicle of Banten when Sunan Gunung Jati and his son Maulana Hasanuddin spread the religion of Islam to Banten Girang, and there they met with King Pucuk Umun who the leader of 98 Brahmins in Pulosari. King Pucuk Umun was willing to embrace Islam if Sunan Gunung Jati accepted the terms he proposed. The condition was cockfighting. If the rooster of Pucuk Umun cock was lost he was willing to convert to Islam. But if Sunan Gunung Jati lose, then Sunan Gunung Jati should follow Pucuk Umun. Sunan Gunung Jati told his son to respond Pucuk Umun's challenge. Finally the cockfight was performed. Thew cock of Pucuk Umun was created from iron sand while Maulana Hasanuddin's cock came from Jin. Finally Pucuk Umun's cock was lost. However Pucuk Umun broke his promise; he did not accept Islam. But his followers led by Brahmins Agus Jo and Agus Jong were willing to convert to Islam.

Gajah Pungkur / Gajah Mungkur ornaments were created by Prince Jabir / Prince Sifat

The composition of its main motif ornament is Gajah Dampit (Twins) standing back to back (Mungkur) Rear Pungkur means. This ornament is constructed using Wadasan structure of elephant style. The supporting ornament is folded (closed) Godong Kluwih made using symmetrical patterns forming the elephant saddle. Godong Kluwih also serves as a divider of Gajah Pungkur ornament which also has symmetrically shape. The element of the ornament is Pandan Wangi, a motif with aromatic pandan. Sulur Kangkung is swamp 
cabbage leaf motif becoming symmetrical sweetener for gajah pungkur and Godong Terate. The philosophy of Gajah Pungkur ornament symbolizes Manunggaling Kawula Gusti teachings (wihdatul wujud). The teaching of this Ibn Arubi are much cited in the scripts of Cirebon Sufism. Gajah symbolizes Kawula, Mount Wadasan symbolizes Gusti (Allah); this motif also symbolizes Hablum minannas. Two elephants were back to back. This ornament also describes the content of Al Qur'an Surat ar-Rahman verse 19 - 20. Pandan wangi describes amalus Sholihah, fruits of those who have been united with God and has done good deed to anyone. Lotus signifies God almighty and Godong Kluwih means aja keluwen. Life should not be excessive in every way, whether in speech, action and expenses.

Sirah Liman / Endas Gajah (Elephant Head) design was created by Prince Jabir / Prince Sipat, with the composition of the main motif of Elephant Head formed with the Patran pattern (leaf strands that make up the motif of elephant head). Strands of covered leaves in the form of tendrils pattern (concatenated) in the vertical direction forming stylized head of Elephant. The main ornament has elements of a closed leaf shape, open leaf, leaf tendril. The supporting ornaments are Gunungan Wadasan, Pandan Wangi Wit, Wit Teratean and Sulur Patran. The philosophy of Sirah Gajah ornament is to show the name of place producing Batik Cirebon Pegajahan. The name Pegajahan itself has been around since the time of Sunan Gunung Jati. Historically, the place was originally an Elephant Cage. One of the concubines of Panembahan Ratu I was the queen from Sarati (Lampung). Sarati itself means Gajah tamer. According to Ki Hamad (Muhammad) from Prince Jaber, from the Prince Sifat, Elephant is a symbol of stupidity. The example is Gajah Banteng Sirah Sinunggal above which Hadts Qudsi is written. The meaning of the symbol of ignorance is he who knows himself he would really know God, and whoever knows God then he really will feel himself stupid. Whoever feels stupid then he really will feel stupid in front of his Lord. Barang siapa sudah merasa bodoh di hadapan Tuhannya, maka sungguh - sungguh sudah sampai ma'rifatnya di hadapan Allah. Anyone who already feel stupid in front of his Lord, then his ma'rifat has really been come to God. Jadi Gajah (bodoh) sabar, pasrah, tawakal merupakan perwujudan sikap dari ma'rifat. So Elephant (dumb) is patient, resigned, tawakal embodying the attitude of ma'rifat. The meaning of the symbol of Wadasan or Batu Karang is the foundation of faith that is not exposed to weather erosion and abrasion of sea water. This symbolizes the strong and unwavering faith

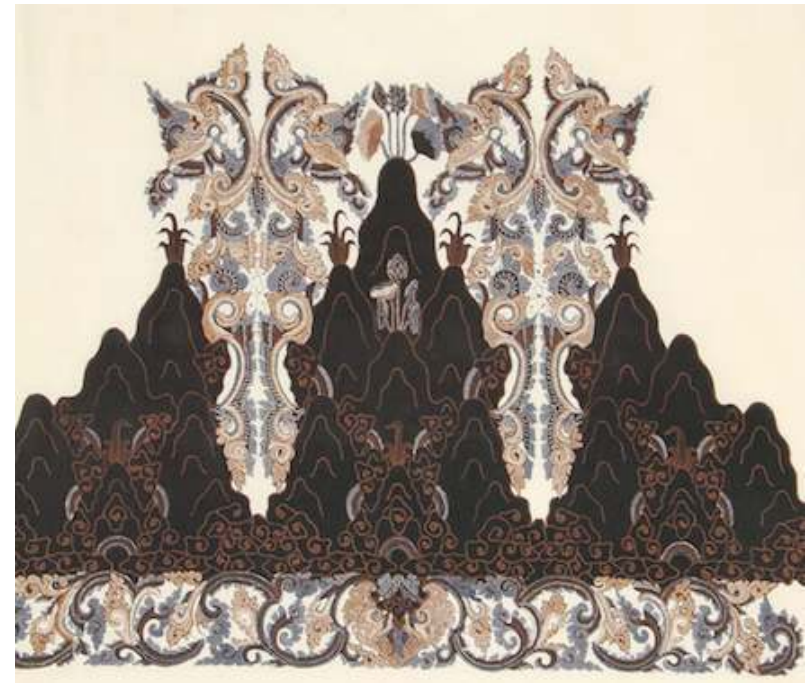

ANALYSIS

Ornaments displayed in designing batik Pegajahan use decoration that looks like that is around the palace of Kasepuhan and Kanoman, while the characteristic of batik decoration of Pegajahan is very prominent and what almost dominates the whole design is the Gajah decoration. The shape of Gajah distillation uses Wadasan ornaments, so it is unlike the elephant picture that is created naturalistically, but resembles the elephant anatomy, such as the shape of the trunk and wide ears that are not owned by other animals. The true teachings of Islam resisted the attempts to put figure into a statue, whether in the shapes of human or animal. Fauna and flora figures are part of the symbolism of the mythological realm system that complements the design of the Hindu Javanese building art, either in the form of statues and reliefs. (Falah Anwar, 65).

Based on the narrative presented by Elang Yoppy, it was exteremely possible the existence of elephant living in the environment of Kasepuhan palace as one vehicle ridden by the king, and perhaps also by 
the special forces of Kasepuhan palace. Sometimes, the elephants were found around Pegajahan that is now used as the name for the area that is Pegajahan. The elephant itself has a representation of power, ignorance, wisdom, virtue and love. This symbolism also has equation with elephant symbolism supported in the Sultanate of Cirebon. The Gajah was commonly called Liman seen as the epitome of a great soul, strength, honesty, stupidity, love and protector. It is used as a measure of the ideal type of personality of Sultan and his descendants (Sulendraningrat 1956: 40). Based on the observation and analysis obtained from some Pegajahan traditional batik decorations some forms of decoration are identified: Elephants, Pandan Wangi, Wild Chickens Alas, Wadasan, Megamendung and Sulur as ropes.

According to Elang Yoppy, the beauty of art owned by some people of Cirebon was inherited by a Wali who helped teach Islam in Cirebon known as Sunan Kalijaga. In addition to teaching Islam, Sunan Kalijaga taught a lot about cultures and arts such as creating Cirebon puppets and paintings containing the teachings of Islam, and one of them is to make batik decorative that is quite beautiful and has quite deep symbolic meanings.

The depth of symbolic meanings of Pegajahan batik decoration shows that the students' creation of art who study Islamic values through a sufi Tarekat Syattariyah show that the beautifu art works can only be brought and produced by the human souls that have goog moral character and comprehensive in practicing their religion properly. Because if an aesthetic is only associated with taste and sensual pleasure, or worldly pleasure, then the value of the art will degenerate. The more we study and explore the works of batik produced from school of Pegajahan, then we will find many other sides of the majority of past history, past knowledge, as well as the culture of indigenous people of Cirebon, especially the descendants of Cirebon palaces with the behavior of the murshid and santri in the implementation of the religious teachings of Islam that are not conflicting but complementary to the culture of indigenous people of Cirebon who first recognized mystical conception of Javanese-Hindu.

\section{CLOSING}

Pegajahan batik decoration is an asset of Cirebon people in general that is very valuable and as an evidence of history that should be explored that traditional batik handicraft of Pegajahan once existed and grew outside the walls of Cirebon palace located not too far from the palace. Pegajahan batik decoration was created by the students who run Islamic Shari'a through tarekat that was taught by Mursid (tarekat teachers) particularly in the area of Pegajahan. Batik Pegajahan is masculine, because the batik makers at that time were usually men

Each batik decoration created by the elders of Pegajahan has a symbolic meaning and teachings to human life especially to his students. The author also believes that in every part of batik decoration contains teachings of Islam that must have a goal and be so made in the selection of the decoration.

Batik Pegajahan is a new discovery and has never been recorded in the repertoire of the Cirebon keratonan batik and probably forgotten at the time of writing by previous researchers. By documenting some batik decoration of Pegajahan and permission given to take part in developing batik Pegajahan, it is expected that Pegajahan batik will be socialized and raised again to the treasury of Cirebon batik with keratonan theme. Without publications and revitalization of the Pegajahan batik, the batik of Pegajahan may be buried forever and has no meaning anymore for future generations.

\section{REFERERENCES}

Al-Ghazali (1993). Kimia Kebahagiaan. Terjemahan Tim Mizan. Bandung: Mizan.

Casta Made, (2008): Batik Cirebon, Sebuah Pengantar Apresiasi, Motif, dan Makna

Simboliknya, Cirebon: Penerbit Bakombudpar Kabbupaten Cirebon.

Dhofier, Zamakhasyari. 1994. Tradisi Pesantren. Jakarta: LP3ES. 
Dhofier, Zamakhsyari. 1985. Tradisi Pesantren: Studi Tentang Pandangan Hidup Kyai. Jakarta: LP3ES.

Hadi Abdul. W.M. (2004): Hermeneutika, Estetika dan Religiusitas, Yogyakarta: Penerbit Matahari, Cetakan Pertama.

Irianto, HR. Bambang dan Hendriyana, Husen (2012) :Makna Simbolik Motif Batik Keraton

Cirebon.

Isniawati, Nina (1988): Simbolisme dalam Seni Batik Keraton Cirebon, Bandung: FISIP

UNPAD.

Koentjaraningrat (1977): Beberapa Pokok Antropologi Sosial. PT Dian Rakyat. Cetakan

Ketiga.

Lombard, D. (2000): Nusa Jawa: Silang Budaya, Batas-Batas Pembaratan, Jilid 1, Jakarta:

PT Gramedia Pustaka Utama dengan Forum Jakarta-Paris dan Ecole francaise

d'Extreme-Orient.

Muhaimin A.G. (2001): Islam dalam Bingkai Budaya Lokal Potret dari Cirebon. Cetakan

Pertama, Penerbit Logos Wacana Ilmu, Ciputat.

Mustafa Zahri, DR. (1982): Kunci Memahami Ilmu Tasawwuf, PT. Bina Ilmu Surabaya

Pabitrakumar Roy (1990). Beauty, Art and Man: Studies in Recent Indian Theorises of Art. Shimla: Indian Institute of Advanced Study

Raofan, Achmad (2010): Tarekat Sattariyah Kraton Kaprabonan Suatu Kajian Filologis, Tesis, Bandung: UNPAD.

Spradley, J. P. (2006): Metode Etnografi, Terjemahan, edisi II cetakan ke-1, Yogyakarta: Tiara Wacana.

Sulendraningrat PS (1972): Purwaka Tjaruban Nagari. Djakarta Bharata.
Sachari, Agus (2003): Pengantar Metodologi Penelitian Budaya Rupa, Desain, Arsitektur, Seni Rupa dan Kriya, Bandung: Penerbit Erlangga, cetakan I.

Sachari, Agus (2004): Peran Nilai Estetis Modern Dalam Perkembangan Desain Abad ke-20 di Indonesia, Disertasi Doktor, Bandung: Institut Teknologi Bandung.

Susanto, S. (1981) Tinjauan Motif-Motif Batik Berbagai Daerah dan Ragam Hias Dalam Seni Batik.

Yudoseputro, W. (2005): Historiografi Seni Indonesia, Sebuah Pemikiran Terwujudnya Sejarah Seni Rupa Indonesia, Bandung : Penerbit ITB. 